
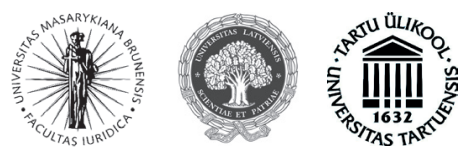

ISSN 1392-6195 (print) ISSN 2029-2058 (online) JURISPRUDENCIJA JURISPRUDENCE 2013, 20(3), p. 1095-1111.

\title{
VIENASMENIO VALDYMO ORGANO TEISINIS STATUSAS: AR IMANOMAS VIENAREIKŠMIŠKUMAS?
}

\author{
Agnè Tikniūtè, Jūratė Usonienè
}

Mykolo Romerio universiteto Teisès fakulteto

Civilinès justicijos institutas

Ateities g. 20, LT-08303 Vilnius, Lietuva

Telefonas (+370 5) 2714587

Elektroninis paštas: agne.tikniute@gmail.com; usoniene@mruni.eu

Pateikta 2013 m. liepos 29 d., parengta spausdinti 2013 m. rugpjūčio 25 d.

doi:10.13165/JUR-13-20-3-12

Anotacija. Straipsnyje nagrinejama įmonès vienasmenio valdymo organo teisinio statuso problematika Lietuvoje susiformavusios teismu praktikos, doktrinos ir teisinio reguliavimo aspektais. Pirmojoje straipsnio dalyje analizuojamas vadovo teisinès padeties dualizmas civilinès ir darbo teisès požiūriu, apžvelgiant galiojantị teisini reguliavima, teisès doktrina ir naujausia teismu praktika, kurioje méginama atriboti darbo teises ir civilines bei bendroviu. teisès taikymo sritis imonés vadovui. Daroma išvada, kad riba tarp darbo teisès ir civilinès teises taikymo vadovo teisiniam statusui tebera neaiski, o ateities teismu sprendimai sunkiai prognozuojami. Straipsnio autoriu nuomone, teismu praktikos kuriamos vadovo teisini statusa reglamentuojančios normos negali suteikti reikalingo teisinio tikrumo, tam bütina teisinio reguliavimo reforma. Antroje straipsnio dalyje ieškoma atsakymo i klausima, kokie yra galimi teisinio reguliavimo modeliai ir kokie pagrindiniai kokybiško teisinio reguliavimo kriterijai. Lyginamuoju aspektu išnagrinejus vienasmenio valdymo organo teisinio statuso reglamentavima, ivardinami pagrindiniai klausimai, kuriuos turètu išspręsti teisinis reguliavimas, ir nurodomi galimi teisinio reguliavimo modeliai. Teikiamas siülymas kurti specialu. 
bendroviu teises teisini reguliavima, atitinkantị verslo poreikius ir suderinta su jau dabar taikoma įmoniu teises doktrina. Straipsnis baigiamas išvadomis ir pasiülymais.

Reikšminiai žodžiai: vienasmenis valdymo organas, vadovo teisinis statusas, vadovo ir imones teisiniai santykiai, vadovo teisine atsakomybe.

\section{İvadas}

Teisinè sistema teisinei taisyklei suteikdama įstatymo formą siekia tam tikrų tikslų, kurie neretai ne vien teisiniai. Chrestomatinis šio teiginio pavyzdys, garsusis $1804 \mathrm{~m}$. Prancūzijos civilinis kodeksas, davęs pradžią kitoms Europos kodifikacijoms, buvo politinio siekio apriboti teisèjų igaliojimus rezultatas. Jau XIX a. Napoleonas siekè redukuoti teisejų veiklą iki biurokratinès teisès taikymo funkcijos, todèl pagal teoriją, kuria buvo grindžiamas Prancūzijos civilinis kodeksas, ịstatymų leidèjas turèjo kurti teisę be spragų, vadinasi, teisèjams liko pareiga tik ją taikyti. Napoleono civiliniu kodeksu siekta tokio aiškaus, ištobulinto ir nuoseklaus reguliavimo, kad teisejjams nereikètų viešai aiškinti, kokie įstatymai, papročiai, praeities sprendimai turètų būti taikomi naujai iškylančioms situacijoms. Tačiau šis projektas pasiteisino tik iš dalies, nes nepavyko sukurti tokio nuoseklaus reguliavimo, kad teisejjams ir asmenims, kurių atžvilgiu šios normos yra taikomos, neliktų abejonių dèl jų teisių ir pareigų apimties. Lietuva taip pat pasirinko prancūziškajji civilinès teisès modelị, todèl teisinès sistemos dalyviai - ne tik teisininkai, bet ir neprofesionalūs teisès „vartotojai“, pagrịstai tikisi, kad teisinis reguliavimas bus jei ir ne be spragų, tai bent toks, kad civilinių teisinių santykių dalyviai galès ịvertinti savo teisių ir pareigų apimtị remdamiesi ịstatymais, o tik išimtiniais ar sudètingais atvejais atsakymo teks ieškoti teismų praktikoje. Tačiau žvelgiant i juridinių asmenų, konkrečiai bendrovių vienasmenių valdymo organų, teisinị reguliavimą Lietuvoje, akivaizdi sisteminé problema, panaši ị tą, su kuria kitados susidūrè ir prancūzai, - teisinès sistemos dalyvių teisių ir pareigų neapibrèžtumas bei teisinio rezultato nenuspèjamumas kasdieniuose teisiniuose klausimuose.

Jau daugiau kaip 12 metų teismų praktika neturi aiškaus atsakymo, kaip turètų būti kvalifikuojamas bendrovès ir jos vadovo teisinis santykis - kaip civilinis, ar vis dèlto darbo? Atrodytų, kaip galëjo atsirasti tokia problema, esant vienareikšmiškam (bent jau nuo 2000 metų $^{1}$ ) įstatymo reguliavimui, pagal kurị bendrovę ir jos vadovą sieja darbo teisiniai santykiai? Šios problemos išsamią analizę darbo teisès požiūriu $2008 \mathrm{~m}$. atliko T. Davulis ${ }^{2}$ ir pripažino, kad Lietuvos Aukščiausiojo Teismo doktrina dèl bendrovès vadovo ịstatyminio atstovo statuso kuriama contralegem: esant vienareikšmiškam ịstatymo reguliavimui, pagal kurị bendrovę ir jos vadovą sieja darbo teisiniai santykiai, prak-

12000 m. liepos 13 d. prièmus naują Lietuvos Respublikos akcinių bendrovių įstatymą (Lietuvos Respublikos akcinių bendrovių įstatymas. Valstybès žinios. 2000, Nr. 64-1914, toliau tekste - ABIt), nebeliko galimybės pasirinkti, ar su vadovu bus sudaryta darbo, ar civiliné sutartis.

2 Davulis, T. Imonès, ịstaigos, organizacijos vadovo teisinio statuso problema Lietuvos teisèje. Privatiné teisé: praeitis, dabartis ir ateitis: liberamicorum Valentinas Mikelenas. Vilnius: Justitia, 2008, p. 99-115. 
tika nesivadovauja (arba tiksliau - dažniausiai nesivadovauja) įstatymo nuostatomis. Darbo teisès specialistų nuomone, teismų praktika sukūrẻ priešingą darbo teisiniams santykiams modelį, kurį B. Martišienè disertacijoje „Darbo santykių reguliavimo civiliniai teisiniai aspektai“ ivardino kaip civilinių santykių su ypatumais ${ }^{3}$. Ji taip pat prièjo prie išvados, kad tokio modelio veikimas yra chaotiškas ir nesistemingas, todèl keistinas grị̌ztant prie darbo santykių su ypatumais modelio ${ }^{4}$. Panašios pozicijos jau anksčiau laikèsi ir T. Davulis ${ }^{5}$. Žvelgiant iš galiojančio teisinio reguliavimo perspektyvos reikètų sutikti su šių autorių nuomone: grịžimas prie bendrovès vadovo, kaip darbo teisinių santykių subjekto su ypatumais, statuso padidintų teisinị tikrumą. Tačiau vargu ar be įstatymo reformos toks grịžimas yra realus, nes daugelis taisyklių jau sukurta teismų praktikos, o dalis klausimų iki šiol sprendžiami prieštaringai. Todẻl šiame straipsnyje siekiama atskleisti, kad esamas reguliavimas ir praktika vadovo teisinio statuso klausimais neužtikrina minimalaus teisinio tikrumo, to nepadarytų ir perëjimas prie vadovo, kaip civilinių santykių subjekto, modelio, nes vadovo teisinio statuso reguliavimas dabar galiojančiomis Lietuvos Respublikos civilinio kodekso ${ }^{6}$ ir $\mathrm{ABI}^{7}$ normomis lemtų dar didesnị neapibrèžtumą. O vertinant, kokios teisés šakos normomis turètų būti sureguliuotas vadovo teisinis statusas, reikètų atkreipti dèmesi ne tik į teisinès politikos motyvus (vienas jų - valstybės biudžetui palankesnis apmokestinimo modelis, kai vadovas yra darbo teisès subjektas), nes šių tikslų galima pasiekti ir kitomis priemonèmis, bet visų pirma i tai, kad vadovo teisinis statusas neatsiejamas nuo bendrovių teisès normų, kurių atžvilgiu darbo teisès normos negali turèti viršenybės ${ }^{8}$.

Kadangi minètuose Lietuvos autorių tyrimuose išsamiai išanalizuota teisinio reguliavimo ir teismų praktikos raida bendrovès vadovo teisinio statuso aspektu, šiame straipsnyje keliamas uždavinys tik atskirais pavyzdžiais parodyti teismų praktikos, kaip teisinio reguliavimo priemonès, nepakankamumą ir įstatymo reformos būtinumą vadovo teisinio statuso klausimuose.

1. Teisinio reguliavimo ir doktrinos įtaka vienasmenio valdymo organo teisinio statuso problemos sprendimui. Kaip 2008 m. teigė T. Davulis, įstatymų leidèjas ,ǐ̌ esmès aiškiai <..> vadovo ir juridinio asmens santykius pripažino ir pripažịsta darbo teisiniais santykiais"9. Jis taip pat nurodè, kad 1998 m. kovo 19 d. ABI pakeitimai ${ }^{10}$, kuriais buvo leista su bendrovès vadovu sudaryti ne tik darbo, bet ir civilinę sutartį, iš

3 Martišienè, B. Darbo santykiu reguliavimo civiliniai teisiniai aspektai. Daktaro disertacija. Socialiniai mokslai (teisè). Vilnius: Vilniaus universitetas, 2012, p. 116-117.

$4 \quad$ Ibid., p. 116.

5 Davulis, T., supra note 2, p.115.

6 Lietuvos Respublikos civilinis kodeksas. Valstybés žinios. 2000, Nr. 74-2262. Toliau tekste - CK.

7 Šiuo metu galioja 2012 m. birželio 19 d. Lietuvos Respublikos akcinių bendrovių įstatymo redakcija (Valstybès žinios. 2012, Nr. 78-4016).

8 Nors Lietuvos Respublikos darbo kodekso (Valstybès žinios. 2002, Nr. 64-2569; toliau tekste - DK) 11 straipsnyje numatyta darbo kodekso viršenybė kitų ịstatymų atžvilgiu, vis dẻlto teisès šakų kolizija vadovo teisinio statuso klausimu negali būti išspręsta darbo teisès naudai, nesukeliant dar didesnių problemų bendrovių teisès srityje.

9 Davulis, T., supra note 2, p. 114.

10 Valstybès žinios. 1998, Nr. 36-961. 
esmès buvo tik darbo teisinio santykio modifikavimas, prisidejjęs prie teismų praktikoje imto vartoti civilinio teisinio santykio termino ${ }^{11}$. $2000 \mathrm{~m}$. liepos $13 \mathrm{~d}$. prièmus naują $\mathrm{ABI}$, vèl nebeliko galimybės pasirinkti, ar su vadovu bus sudaryta darbo, ar civilinè sutartis. Tikètina, kad 1998 m. kovo 19 d. ABI pakeitimai lèmé, kad teismai èmè tolti nuo vadovo, kaip darbo teisès subjekto, sampratos: precedentinèje $2001 \mathrm{~m}$. bylos $V$. P. v. Radviliškio rajono savivaldybe, UAB „Radviliškio autobusu parkas “12 nutartyje buvo suformuluota taisyklè (dar taikant 1964 m. Civilinį kodeksą), kad administracijos vadovo ir bendrovès santykiai savo esme yra pavedimo, t. y. civiliniai teisiniai, santykiai. Lietuvos Aukščiausiasis Teismas pasisakè, kad administracijos vadovo buvimas bendrovès organu suponuoja tai, jog daugelis administracijos vadovo teisių ir pareigų atsiranda įstatymo, o ne sutarties pagrindu. Pozicijos, kad vadovą ir bendrovę sieja civiliniai teisiniai santykiai, Lietuvos Aukščiausiasis Teismas nuosekliai laikosi ir dabartineje savo praktikoje, nepaisant to, kad teisinis reguliavimas nebenumato galimybès vadovui su bendrove sudaryti kitokią nei darbo sutartit ${ }^{13}$.

Taigi $2000 \mathrm{~m}$. pasikeitęs teisinis reguliavimas, paneigęs bendrovès ir vadovo galimybę pasirinkti, ar sudaryti darbo, ar civilinę sutartị, teismų praktikos nepakeitè. Taip pat ịtakos jai beveik neturejo ir 2000 m. CK įsigaliojimas kartu su nauja valdymo organų teisinio statuso teorija, pakeitusia iki pagal 1964 m. Civilinį kodeksą galiojusią sampratą: doktrina ir teisinis reguliavimas perejo nuo valdymo organų, kaip juridinio asmens atstovų, prie valdymo organų, kaip paties juridinio asmens valios reprezentantų sampra$\operatorname{tos}^{14}$, todėl, atrodytų, pavedimo santykių tarp vadovo ir bendrovès kvalifikavimas nebeatitiko naujos doktrinos. Specialūs įstatymai taip pat tolo nuo vadovo, kaip akcininkų atstovo, sampratos, įtvirtindami vis daugiau valdymo organų įstatyminių pareigų, - štai ir dabar galiojančioje ABI redakcijoje laikomasi požiūrio, kad valdymo organai turi įstatymo numatytą kompetenciją ir atsakomybę, kurios negali siaurinti ir keisti akcininkai savo nuožiūra ${ }^{15}$.

Tačiau teismų praktika ne tik nesikeitè, bet formavo doktriną, kuri buvo inkorporuota ir ị CK Antrosios knygos komentarą: pavyzdžiui, komentaro autoriai aiškindami 2.81 straipsnio 1 dali nurodo, kad ,(j)uridiniai asmenys ịgyja civilines teises, prisiima

11 Davulis, T., op. cit., p. 114.

12 Lietuvos Aukščiausiojo Teismo Civilinių bylų skyriaus teisejjų kolegijos $2001 \mathrm{~m}$. spalio 16 d. nutartis civilineje byloje V. P. v. Radviliškio rajono savivaldybe, UAB „Radviliškio autobusu parkas “ (bylos Nr. 3K-7-760/2001).

13 Žr. Lietuvos Aukščiausiojo Teismo Civilinių bylų skyriaus teisėjų kolegijos 2009 m. lapkričio 20 d. nutartị civilinèje byloje BUAB ,, Optimalūs finansai “ v. G. P. (bylos Nr. 3K-7-444/2009, Lietuvos Aukščiausiojo Teismo Civilinių bylų skyriaus teisėjų kolegijos $2009 \mathrm{~m}$. lapkričio 20 d. nutartị civilinėje byloje Nr. 3K7-444/2009), Lietuvos Aukščiausiojo Teismo Civilinių bylų skyriaus teisejjų kolegijos $2012 \mathrm{~m}$. lapkričio 16 d. nutarti civilinejje byloje Bankrutuojanti UAB ,IBCA trobos “ v. A. G. (bylos Nr. 3K-3-493/2012).

14 Plačiau apie tai, kad valdymo organai nėra juridinio asmens atstovai tradicine pavedimo prasme, žr. Mikelènas, V.,et al. Lietuvos Respublikos civilinio kodekso komentaras. Antroji knyga. Vilnius: Justitia, 2002, p. 259.

15 Valdymo organai nèra atstovai, pavyzdžiui, ABI 34 straipsnio 5 dalyje numatyta, kad įstatuose gali būti numatyta, jog valdyba prieš priimdama šio straipsnio 4 dalies 3, 4, 5 ir 6 punktuose nurodytus sprendimus turi gauti visuotinio akcininkų susirinkimo pritarimą. Visuotinio akcininkų susirinkimo pritarimas nepanaikina valdybos atsakomybės už priimtus sprendimus. 
civilines pareigas ir jas igyvendina per savo organus, kurie sudaromi ir veikia pagal įstatymus ir juridinių asmenų steigimo dokumentus", ir teigia, kad juridinio asmens organo narys, išskyrus juridinio asmens organo dalyvius, gali būti bet kada atšauktas, šị teigini pagrịsdami tik teismų praktika, interalia ir jau minèta byla $V$. P. v. Radviliškio rajono savivaldybe், UAB ,Radviliškio autobusu parkas "16. Taigi Lietuvoje formavosi civilinès ir precedentinès teisès hibridas, kai teismai kūrè taisykles ir ịmonių teisès doktriną ne dèl įstatymo spragų, bet esant aiškiam teisiniam reguliavimui. Šio reiškinio priežastims išsamiai analizuoti nepakaktų šio straipsnio apimties, tad čia tik pažymėsime, kad šią teismų praktikos tendenciją lèmè tai, kad teisinis reguliavimas vėlavo, neatitiko apyvartos poreikių, o kartais tiesiog buvo kuriamas neatsižvelgiant i fundamentalius įmonių teisès principus.

Jau 2001 m. Lietuvos Aukščiausiasis Teismas atsakè i klausimą, ar bendrovès direktorius yra darbo, ar civilinès teisès subjektas sutarties su bendrove nutraukimo prasme, nurodydamas, kad ši sutartis gali būti nutraukta be priežasties. Toliau praktikai tapo aktualu, kokia apimtimi vienasmeniam valdymo organui taikoma darbo teisè. I šị klausimą Lietuvos Aukščiausiasis Teismas atsakè 2001 m. lapkričio 26 d. nutartyje, priimtoje civilineje byloje $P$. D. v. AB ,Žalvaris“"17, o atsakymas buvo toks: „bendrovès ir jos vadovo darbo sutarties pagrindu atsiradusius santykius darbo teisés normos reglamentuoja tiek, kiek tai susiję su bendrovès vadovo teise pasinaudoti socialinėmis garantijomis, darbų saugos ir apmokèjimo už darbą tvarkos nustatymu, darbo sutarties pasibaigimo priežasties formulavimo, darbo sutarties nutraukimo ir atleidimo iš pareigų įforminimo bei atsiskaitymo tvarkos reglamentavimu“. Tokia praktika, jei jos būtų nuosekliai laikytasi, atitiktų B. Martišienès disertacijoje siūlomą modelị, pagal kurị direktorius - tai darbo teisinių santykių subjektas su tam tikrais ypatumais. Tačiau teismai ir toliau kūrè naujas taisykles, vis labiau direktoriaus teisinị statusą darydami suigeneris teisiniu statusu, nes nuosekliai nebuvo laikomasi nei galiojančių darbo teisès normų, nei precedentų, kuriais buvo pakeistos galiojančios normos. I klausimą, ar darbo teisès normos taikomos atsiskaitymų tvarka nutraukus darbo sutarti su direktoriumi, nutartyje byloje Z. Z. v. UAB , Šiaulių aerouostas "18 buvo atsakyta neigiamai, taip dar labiau nutolstant nuo darbo teisiniams santykiams taikomų taisyklių. Ta pačia linkme vystèsi ir teismų praktika klausimu, ar bendrovès vadovas gali būti atleistas iš darbo nesilaikant darbo teisèje numatytų atleidimo procedūrų. I šị klausimą teigiamai buvo atsakyta byloje $V$. S. v. Kooperatine bendrove Lietuvos kooperatyvu sajunga ${ }^{19}$, nurodant, kad darbdavys tik privalo įforminti darbo sutarties pasibaigimą pagal DK 124 straipsnio 1 punktą (darbo sutarties pasibaigimas kitų įstatymų nurodytais pagrindais) ir specialiojo įstatymo - Akcinių bendrovių įstatymo - konkretų pagrindą ${ }^{20}$. Paradoksalu, kad

16 Mikelènas, V., et al., supra note 14, p. 180.

17 Lietuvos Aukščiausiojo Teismo Civilinių bylų skyriaus teisejų kolegijos $2001 \mathrm{~m}$. lapkričio 26 d. nutartis civilinėje byloje P. D. v. AB ,Žalvaris “ (byla Nr. 3K-3-1200).

18 Lietuvos Aukščiausiojo Teismo Civilinių bylų skyriaus teisejų kolegijos $2003 \mathrm{~m}$. sausio 8 d. nutartis civilineje byloje Z. Z. v. UAB , Šiauliu aerouostas “ (byla Nr. 3K-3-6/2003).

19 Lietuvos Aukščiausiojo Teismo Civilinių bylų skyriaus teisẻjų kolegijos $2006 \mathrm{~m}$. vasario 15 d. nutartis civilineje byloje $V . S . \quad$ v. Kooperatine bendrove Lietuvos kooperatyvu sajunga (byla Nr. 3K-3-123/2006).

20 Žr. Lietuvos Aukščiausiojo Teismo Civilinių bylų skyriaus teisẻjų kolegijos $2001 \mathrm{~m}$. lapkričio $26 \mathrm{~d}$. nutartị civilineje byloje P. D. v. AB ,Žalvaris “ (bylos Nr. 3K-3-1200/2001), taip pat Lietuvos Aukščiausiojo 
2010 m. balandžio 30 d. nutartyje byloje J. B. B. v. UAB , Neogroup “21 buvo prieita prie priešingos išvados, ,jog tai, kad darbo sutartis su bendrovès vadovu nutraukiama ne DK, o specialiojo Akcinių bendrovių įstatymo ịtvirtintais pagrindais ir tvarka, neatima galimybès bendrovei (darbdaviui) ir bendrovès vadovui (darbo santykių subjektui) susitarti dèl papildomų darbo sutarties sąlygų, ir tokiu atveju šios sutarties sąlygos, jeigu dẻl jų šalys susitaria, tampa joms privalomos, t. y. turi ịstatymo galią (CK 6.189 straipsnio 1 dalis)“. Taisyklé, kad vadovo teisinį santykị su bendrove darbo teisès normos reglamentuoja tiek, kiek tai susiję su bendrovès vadovo teise pasinaudoti socialinėmis garantijomis, darbų saugos ir apmokèjimo už darbą tvarkos nustatymu, darbo sutarties pasibaigimo priežasties formulavimo, darbo sutarties nutraukimo ir atleidimo iš pareigų įforminimo bei atsiskaitymo tvarka, taip pat nèra nuosekliai taikoma. Antai, pagal teismų praktiką vadovas gali netekti teisès ị išeitinę išmoką, nes net ir nesant vadovo kaltų veiksmų darbo teisès prasme, jo veiksmai gali būti vertinami kaip neteisèti civilinès teisès prasme. Pavyzdžiui, byloje $J$. B. v. AB Turto bankas $^{22}$ teismas nusprende, kad bendrovès administracijos vadovo teisinè padètis i̇monèje lemia tai, kad jam keliami kitokie reikalavimai negu kitiems įmonès darbuotojams, taigi ir bendrovės vadovo kaltè dèl atleidimo iš pareigų turi būti vertinama pagal kriterijus, nustatytus atsižvelgiant ị jo teisini statusą, o ne vertinant jo veiksmus drausminių nuobaudų už darbo drausmès pažeidimus skyrimo požiūriu. Šie pavyzdžiai rodo, kad teismų praktika nutolo nuo bendrovès vadovo, kaip darbo teisinių santykių subjekto, sampratos, ir kaip pabrèžiama, nuo ịstatymo leidejo valios ${ }^{23}$ ne tik vadovo atleidimo iš pareigų ir civilinès atsakomybès klausimuose, bet ir tuose klausimuose, kur pagal pačios teismų praktikos suformuluotą taisyklę vis dar turètų būti taikomos darbo teisès normos, jų taikymas nèra nuoseklus.

2009 m. precedentinèje nutartyje byloje BUAB ,Optimalūs finansai “ v. G. P. ${ }^{24} \mathrm{dar}$ kartą buvo iškeltas klausimas, kokia apimtimi direktorius yra darbo teisès, o kokia civilinės teisės subjektas. Šioje nutartyje išplèstinè teisèjų kolegija, remdamasi ta pačia atstovavimo pagal įstatymą ir pavedimo argumentacija, suformulavo kriterijų, pagal kurị „vidiniuose“ santykiuose vadovas vertintinas kaip darbo teisinių santykių subjektas, o „išoriniuose“ - kaip bendrovès, t. y. juridinio asmens, valdymo organas (ir atstovas)“. Šioje byloje Lietuvos Aukščiausiasis Teismas pabandè sugrižti prie vadovo, kaip darbo teisinių santykių subjekto, pripažinimo, neatsisakant civilinio teisinio statuso elementų. Teismas pripažino vadovo teisinès padèties dualizmą ir išaiškino, kad „vidiniuose“ santykiuose vadovas veikia organizuodamas kasdienę bendrovès veiklą, priimdamas, atleisdamas, skatindamas, bausdamas darbuotojus, vadovas vertintinas kaip darbo teisiniu

Teismo Civilinių bylų skyriaus teisëjų kolegijos $2007 \mathrm{~m}$. spalio $12 \mathrm{~d}$. nutartị civilinëje byloje A. M. v. UAB „Vités valdos “ (bylos Nr. 3K-3-397/2007).

21 Lietuvos Aukščiausiojo Teismo Civilinių bylų skyriaus teisèjų kolegijos $2010 \mathrm{~m}$. balandžio $30 \mathrm{~d}$. nutartis civilinèje byloje J. B. B. v. UAB „Neogroup“ (bylos Nr. 3K-3-157/2010).

22 Lietuvos Aukščiausiojo Teismo Civilinių bylų skyriaus teisèjų kolegijos $2012 \mathrm{~m}$. gegužès 28 d. nutartis civilineje byloje $J$. B. v. AB Turto bankas (bylos Nr. 3K-3-252/2012).

23 Davulis, T., supra note 2, p. 114.

24 Lietuvos Aukščiausiojo Teismo Civilinių bylų skyriaus teisèjų kolegijos 2009 m. lapkričio 20 d. nutartis civilinèje byloje $B U A B$,Optimalūs finansai“ “ v. G. P. (bylos Nr. 3K-7-444/2009). 
santykių subjektas, o ,išoriniuose“, t. y. veikdamas bendrovès vardu santykiuose su kitais asmenimis, - kaip bendrovès, t. y. juridinio asmens, valdymo organas (ir atstovas) ${ }^{25}$.

Apibendrinant galima teigti, kad iš esmès direktoriaus teisinès padèties klausimuose vèl buvo grižta i pradine padèti, nes direktoriaus, kaip darbo teisès subjekto ir civilinès teisés subjekto, statusų atribojimo kriterijus išliko neaiškus. Galima nesunkiai prognozuoti, kad nutartyje byloje $B U A B$,Optimalūs finansai“ v. G. P. suformuluota doktrina - ne pabaiga, o tik laikinas stabtelèjimas kuriant vadovo teisinị statusą reglamentuojančią teisę, nes riba tarp darbo teisès ir civilinès teisès taikymo vadovo teisiniam statusui tebėra neaiški ir dar daug aktualių praktikai klausimų neatsakyta (vadovo teisẻ perigalioti, galimybė direktoriaus darbo sutartyje numatyti civilinès atsakomybès ribojimą ir netaikymą, laikinai einančio direktoriaus pareigas ịgaliojimai veikti bendrovės vardu (kol direktorius serga, atostogauja, yra vaiko priežiūros atostogose) ir kt.).Teismų praktikos sukurtos taisyklès yra bendro pobūdžio, todèl tebėra neaišku, koks bus konkretus rezultatas, jei bylos faktai bus kiek specifiškesni. Pavyzdžiui, CK komentare nuosekliai laikomasi požiūrio, kad direktorius gali būti bet kada atšauktas ${ }^{26}$, tačiau ar tai reiškia, kad juridinis asmuo, atstovaujamas akcininkų susirinkimo, gali susitarti kitaip, pavyzdžiui, sudaryti terminuotą darbo sutartį, pusės metų įspejjimo terminą ar pan., ar, priešingai, ši norma imperatyvi ir bet koks susitarimas bus niekinis? Jei negalima susitarti netaikyti atšaukimo taisyklès, tai gal galima susitarti dèl kompensacijos nutraukus darbo sutarti ar atsakomybès ribojimo?

Tai, kad vieningo doktrinos taikymo pripažistant vadovo teisinio santykio dualizmą nepavyksta pasiekti, iliustruoja ir teismų praktika po bylos $B U A B$,,Optimalūs finansai “ v. G. P sprendimo. Štai minètos bylos Lietuvos Respublikos švietimo ir mokslo ministerija v. UAB ,,Mokslo aidai“ direktorius J. S., likviduojama UAB, ,Mokslo aidai“ ir $k t$. nutartyje likviduojamos bendrovès direktoriaus atsakomybę už neteisètai padidintą darbo užmokestį direktoriaus pavaduotojui - atsakovo sūnui ir finansininkei - atsakovo sūnaus sutuoktinei pripažino kylančia iš darbo santykių ir todèl materialine, o nutartyje byloje Bankrutuojanti $U A B$,IBCA trobos" v. A. G. direktoriaus atsakomybę už neteisètai neišmokètą darbo užmokesti jau kvalifikavo kaip civilinę. Tokiam skirtingam veiksmų, susijusių su darbo užmokesčio mokèjimu, kvalifikavimui buvo faktinis pagrindas: pirmuoju atveju direktorius padarè žalą likviduojamai bendrovei, taigi faktiškai akcininkams, antruoju - bankrutuojančiai bendrovei, todèl žala realiai buvo padaryta tretiesiems asmenims - kreditoriams. Tačiau ar toks diferencijavimas tarp materialinès ir civilinės atsakomybės yra pagrịstas, ypač jei jis nekyla iš aiškios teisès normos ir nèra exante žinomas civilinės apyvartos dalyviams? Akivaizdu, kad tiek vidiniuose, tiek išo-

25 Taip pat žr. Lietuvos Aukščiausiojo Teismo Civilinių bylų skyriaus teisejų kolegijos $2011 \mathrm{~m}$. gruodžio 19 d. nutartị civilinèje byloje Lietuvos Respublikos švietimo ir mokslo ministerija v. UAB „Mokslo aidai “ direktorius J. S., likviduojama UAB ,,Mokslo aidai “ ir kt. (bylos Nr. 3K-3-535/2011). Panašios pozicijos laikytasi Lietuvos Aukščiausiojo Teismo Civilinių bylų skyriaus teisèjų kolegijos 2009 m. gruodžio $18 \mathrm{~d}$. nutartyje civilinejje byloje $A B$,Mažeikiu nafta “ v. I. D. (I. D.) ir kt. (bylos Nr. 3K-3-446/2009), kurioje Teismas išaiškino, kad tais atvejais, kai bendrovès vadovas padaro bendrovei žalos netinkamai organizuodamas kasdienę bendrovės veiklą, t. y. netinkamai atlikdamas savo kaip vadovo pareigas „vidiniuose“ santykiuose, tai dèl jo atsakomybès spręstina pagal darbo teisès normas.

Mikelènas, V., et al.,supra note 14, p. 180. 
riniuose santykiuose vadovas gali padaryti įmonei žalos, pavyzdžiui, pirkdamas įrangą įmonès veiklai už didesnę nei rinkos kainą arba mokėdamas didelius atlyginimus su juo susijusiems asmenims. Visais tokiais atvejais jis pažeidžia pareigas pačiam juridiniam asmeniui ir tai jau įstatymo leidèjo valios ir doktrinos klausimas, ar bus leista jo atsakomybę riboti, ir jei taip, tai kokia apimtimi bei priemonėmis. Vienas iš atsakomybès ribojimo būdų ir dabar yra nustatytas Lietuvos teisèje - tai ribojimas darbo teisès normomis. Griežtai laikantis ABI ịtvirtinto reguliavimo, pagal kurị su bendrovès vadovu sudaroma darbo sutartis ir gali būti sudaryta pilnos materialinès atsakomybès sutartis, galima būtų teigti, kad akcininkai, nesudarydami pilnos materialinès atsakomybès sutarties su vadovu, sutinka apriboti jo atsakomybę 27 . Tačiau ar tai suderinama su bendrovių teisès doktrina? Atsakymas nevienareikšmiškas, ir šis klausimas analizuojamas straipsnio 2 skyriuje, bet vien iš trumpos teismų praktikos apžvalgos aišku, kad toks pažodinis ABI 37 straipsnio 4 dalies aiškinimas nebuvo priimtas praktikoje dèl svarbių motyvų.

2. Vienasmenio valdymo organo teisinis statusas - sui generis institutas? Literatūroje įvardinti pagrindiniai praktikos, traktuojančios bendrovès vadovą kaip civilinių santykių subjektą, trūkumai. Greta to, kad ji iškreipia įstatymo leidejjo ketinimus, ši praktika sukuria papildomų problemų vertinant civilinės teisės nesureguliuotus bendrovès ir jos vadovo teisinio santykio aspektus ${ }^{28}$. Abu šie trūkumai akivaizdūs - teisinių santykių dalyviai negali prognozuoti teisinio rezultato, nes nèra tikri, ar bus laikomasi įstatymo leidèjo valios, o jei taip, tai kokia apimtimi. Tačiau ar šị trūkumą pašalintų nuoseklus lexlata taikymas ir bendrovès vadovo traktavimas kaip darbo santykių subjekto su ypatumais? Pati teismų praktikos raida parodo, kad atsakymas greičiau neigiamas, nes jau daugiau kaip dešimtmetį bandoma precedentais keisti esamą teisinị reguliavimą. Vieningai taikoma tik viena taisyklè, dabar jau įtvirtinta ir ABI, pagal kurią vadovą galima be priežasties atšaukti iš pareigų ${ }^{29}$.

Pagrindinė doktrininè problema, kurios nepavyko išspręsti galiojančiam teisiniam reguliavimui, tai suderinti imperatyvų darbo teisès režimą su imperatyviu bendrovių teisès reguliavimu. Juk darbo teisès normos negali ịpareigoti akcininkų susirinkimo laikytis darbo sutartyje tarp bendrovės vadovo ir bendrovės numatytų sąlygų, nekeisti jų naujais nutarimais ir pan., kadangi bendrovès vadovas visų pirma yra bendrovès organas, kurio veiklą reglamentuoja CK, ABI, įstatai ir akcininkų susirinkimo nutarimai ir tik inter alia darbo sutartis. Todèl nèra proporcinga įtvirtinti darbo teisès viršenybę visų šių teisès aktų atžvilgiü ${ }^{30}$.

Straipsnio autorių nuomone, teismų praktikos kuriamos vadovo teisinị statusą reglamentuojančios normos negali suteikti reikalingo teisinio tikrumo, tam būtina teisinio

27 T. Davulis, nors ir siūlydamas kvalifikuoti bendrovès vadovo statusą kaip darbo teisinių santykių su ypatumais, pabrěžia, kad dabartinis DK reguliavimas dẻl materialinès atsakomybès nèra be priekaištų, ir abejoja, ar pagal dabar galiojantị materialinès atsakomybės sutarties apibrèžimą vadovas visais atvejais yra tinkamas subjektas sudaryti materialinès atsakomybès sutartį. Žr. Davulis, T., supra note 2, p.105.

28 Žr. ibid., p. 114.

29 Žr. išsamią analizę ibid., p. 106-112.

30 Kaip minèta, Lietuvoje ịtvirtinta darbo teisès viršenybė vadovo teisinio statuso klausimais, žr. DK 11 straipsnic. 
reguliavimo reforma. Tam tikri atskiri veiksmai jau matomi, pavyzdžiui, ABI pagaliau buvo išspręsta vadovo atsistatydinimo ir išbraukimo iš Juridinių asmenų registro proble$\mathrm{ma}^{31}$, tačiau esminiam vadovo teisinio statuso problemos sprendimui reikalingas kompleksinis reguliavimas.

Kokybiško reguliavimo kriterijų nustatymas yra platus ir atskiro tyrimo reikalaujantis objektas, tačiau minimalūs reikalavimai teisiniam reguliavimui, ypač skirtam reguliuoti ekonominius santykius, išskiriami ịmonių teisės specialistų, būtų tokie: pirma, reguliavimas neturi prieštarauti standartinei verslo praktikai, antra, reguliavimo rezultatas turi būti prognozuojamas, nes nepateisinama, kad elementarių įmonių teisès normų turinys atskleidžiamas tik teisme, ir trečia, taisyklès turi siekti aiškumo ir apibrèžtumo ${ }^{32}$.

Dabartinis vienasmenio valdymo organo teisinio statuso reguliavimas minètų kriterijų neatitinka: įstatymo reguliavimas prieštarauja verslo praktikai, o šio trūkumo taisymas per interpretavimą teismuose lemia teisinio tikrumo ir apibréžtumo stoką. Klausimas, kokiu teisès aktu turètų būti sureguliuoti vadovo teisinio statuso klausimai, nėra šio straipsnio objektas, be abejonès, dalis klausimų gali būti sureguliuota ir DK. Tačiau atkreiptinas demesys, kad vadovo teisinio statuso problema apima platesnị spektrą ịmonių teisès klausimų nei vien vadovo statuso dualizmas, o dalis šių klausimų jau sureguliuota ABI (sutarties sudarymas, nutraukimas, išregistravimas iš Juridinių asmenų registro, ispejjimo terminai), todèl svarstytina ir alternatyva reguliuoti vadovo teisinio statuso klausimus ABI.

Akivaizdu, kad vadovo teisinio statuso tinkamam reglamentavimui nepakanka dabar galiojančių DK, CK ir ABI normų. Darbo teisės režimas yra per daug ribojantis (pavyzdžiui, akcininkai negali atšaukti direktoriaus, esančio vaiko priežiūros atostogose), nesuderintas su bendrovių teisès doktrina, be to, nemažai klausimų, tiesiogiai susijusių su bendrovès vadovo ịgaliojimų klausimais, nepatenka arba tik iš dalies patenka ị darbo teisės reguliavimo dalyką. Pavyzdžiui, bendrovės atstovavimo klausimai ne kartą buvo nagrinèti Lietuvos Aukščiausiojo Teismo ir priimti sprendimai taip pat buvo contra legem, tik ši kartą ABI atžvilgiu. Pavyzdžiui, ị klausimą, kas turi pareigą išrinkti direktorių, jei jis mirè, o bendrovejje nèra stambaus akcininko, Lietuvos Aukščiausiasis Teismas atsakè, kad akcininkai, turintys ne mažiau kaip 10 proc. bendrovès akcijų $u^{33}$, nors akcininkai, turintys ne mažiau kaip 10 proc. bendrovės akcijų, turi tik iniciatyvos teisę sušaukti akcininkų susirinkimą (ABI 23 straipsnio 1-3 dalys). Arba ị klausimą, kas

31 ABI 37 straipsnio 2009 m. gruodžio 15 d. redakcija (Valstybés žinios. 2009, Nr. 154-6945).

32 Hay, J. R.; Shleifer, A.; Vishny, R. W. Toward a the oryoflegalreform. European Economic Review. 1996, 49: 559-567, p. 561.

33 Lietuvos Aukščiausiojo Teismo Civilinių bylų skyriaus teisejjų kolegijos 2009 m. liepos 9 d. nutartis civilinejje byloje $B U A B$,, Alveronas “ v. I. S., R. P. ir kt. (bylos Nr. 3K-3-329/2009). Šios bylos faktai tokie: BUAB „Alveronas“Kauno apygardos teismo 2006 m. vasario $10 \mathrm{~d}$. nutartimi iškelta bankroto byla. İmonès direktoriaus pareigas èjęs A. Č. 2002 m. rugpjūčio 15 d. mirè. Atsakovai turèjo kiekvienas po 11 proc. įmonès akcijų. Akcininkai pagal turimą akcijų skaičių galejjo tik inicijuoti visuotinio susirinkimo sušaukimą, bet šaukti jị turèjo valdyba, bendrovės vadovas ar akcininkai, turintys daugiau kaip 1/2 dalị balsų (ABI 26 straipsnio 2 dalis). Akcininkų susirinkimai ir anksčiau nebuvo šaukiami ir nevyko, todèl akcininkų elgesys nesidomint bendrovès veikla tik patvirtina, kad jų santykis su bendrove, ịtaka jos veiklai bei dalyvavimas bendrovès veikloje buvo minimalūs. 
atstovauja bendrovei, kai vadovas yra atšaukiamas (t. y. igaliojimai pasibaigia bendrovių teisės prasme, bet nenutrūksta darbo teisės prasme), buvo atsakyta, kad, pasibaigus bendrovès vadovo igaliojimų terminui, direktorius gali atstovauti bendrovei, jeigu nèra išrinktas kitas vadovas ${ }^{34}$.

Akivaizdu, kad klausimą, kas atstovauja bendrovei, jei vadovo igaliojimai yra pasibaigę, turètų reglamentuoti ABI, o nesant tokios taisyklès teismai yra priversti suktis iš padėties, kad direktoriaus nepaskyrę akcininkai neišvengtų atsakomybès. Tačiau teismų praktikos taisyklè ne tik yra siurprizinè teisinio reguliavimo atžvilgiu, bet ir neskatinanti dalyvavimo akciniame kapitale. Šiuo požiūriu labai naudinga būtų ABI numatyti nuostatą, analogišką galiojančiai Nyderlandų bendrovių teisèje, pagal kurią turi būti numatyta taisyklè, kaip bendrove bus laikinai valdoma ir atstovaujama, jei nebus direktoriaus, ar jo igaliojimai bus suspenduoti ${ }^{35}$. Tokia taisyklè išspręstų daugeli praktinių problemų dèl bendrovès atstovavimo, ypač kai akcininkai nesusitaria dèl naujo direktoriaus kandidatūros ir pan.

Žvelgiant ị Europos valstybių patirtį, reikia pripažinti, kad vadovo teisinio statuso klausimai yra detaliai reglamentuoti įmonių įstatymuose. Jungtinèje Karalystèje galioja 2006 metų Bendrovių įstatymas (CompaniesAct 2006 ${ }^{36}$ ), Vokietijoje vadovo teisinis statusas reglamentuojamas atskirų rūšių įmonių įstatymuose: Akcinių bendrovių įstatyme $\left(A k t G^{37}\right)$, Uždaro tipo bendrovių įstatyme $\left(G m b H G^{38}\right)$. Atskirose valstybėse išsiskiria praktika dẻl darbo teisès normų taikymo vadovui. Pavyzdžiui, Nyderlanduose galioja mišrus modelis, pagal kurị santykius tarp direktoriaus ir bendrovès reguliuoja ir darbo, ir įmonių teisè $\dot{3}^{39}$. Vadovai gali būti bet kada atšaukti iš pareigų organo, turinčio kompetenciją juos skirti, sprendimu ${ }^{40}$. Tačiau įstatai gali numatyti papildomą reikalavimą, kad tokiam sprendimui reikia kvalifikuotos atitinkamo organo daugumos pritarimo. Taip pat Nyderlandų ribotos atsakomybės bendrovių įstatymas leidžia sustabdyti vadovų igaliojimus (ịprastai tai - stebėtojų tarybos kompetencija), o ịgaliojimų sustabdymas gali būti bet kada anuliuotas akcininkų susirinkimo.

Kaip minèta, Jungtinejje Karalystejje vadovo teisinį statusą reglamentuoja Bendrovių įstatymas. Fundamentali akcininkų teisè atšaukti direktorių daugumos balsu negali būti pakeista įstatais ar akcininkų sutartimis ${ }^{41}$, tačiau direktorius išlaiko teisę reikalauti nuostolių atlyginimo dèl sutarties pažeidimo ${ }^{42}$. Direktorius gali skirti ịgaliotinị (alternate),

34 Lietuvos Aukščiausiojo Teismo Civilinių bylų skyriaus teisèjų kolegijos 2007 m. kovo 26 d. nutartis civilineje byloje Antstolis A. S. v. UAB „Biriu kroviniu terminalas “ (bylos Nr. 3K-3-238/2007). Teisèjų kolegija padare išvadą, kad generalinio direktoriaus ịgaliojimai turetų baigtis, kai visuotinis akcininkų susirinkimas išrinks naują bendrovès vadovą ir šis pradès dirbti.

35 Corporate Business Forms in Europe. A Compendium of Public and Private Limited Companies in Europe. Edited by Dornseifer, F. Sellier publishers, 2005, p. 583, par.74.

36 [interaktyvus]. [žiūrèta 2013-07-01]. <http://www.legislation.gov.uk/ukpga/2006/46/contents>.

37 [interaktyvus]. [žiūrèta 2013-07-01]. <http://www.gesetze-im-internet.de/aktg/>.

38 [interaktyvus]. [žiūrèta 2013-07-01]. <http://www.gesetze-im-internet.de/gmbhg/>.

39 Corporate Business Formsin Europe. A Compendium of Publicand Private Limited Companiesin Europe, op. cit., p. 582, par. 72 .

40 Ibid.

41 Supra note 35 , p. 75, par. 105.

42 Ibid., p.82, par. 171. 
jei tokia teisé numatyta įstatuose ${ }^{43}$. Pagal Jungtinès Karalystės teisę, įmonè negali padengti nuostolių (indemnify), kuriuos patyrè direktoriai ir auditoriai atlygindami žalą, padarytą dèl savo neatsargumo ar tyčios, tačiau gali kompensuoti jų bylinėjimosi išlaidas priklausomai nuo bylos baigties ${ }^{44}$. Imonè taip pat negali išmokèti direktoriui kompensacijos dèl pareigų praradimo ar išejjimo ì pensiją, negavusi akcininkų susirinkimo pritarimo (Bendrovių įstatymo 312 straipsnis) ${ }^{45}$. Tačiau Jungtinès Karalystès teisè taip pat numato galimybę sudaryti terminuotą sutartị su direktoriumi, kurios negalima bet kada nutraukti. Šiai sutarčiai sudaryti reikia gauti akcininkų susirinkimo pritarimą ${ }^{46}$.

Pagal Vokietijos teisę, bendrovès (tiek GmbH, tiek AG) vadovo sutartis su įmone ir bendrovès organų sprendimas dèl vadovo skyrimo ir atšaukimo laikomi dviem savarankiškais teisiniais santykiais. Pavyzdžiui, akcinės bendrovės (AG) valdybos narių paskyrimas yra bendrovès aktas, atskiras nuo darbo sutarties sudarymo su atskirais nariais, todèl valdybos nario atšaukimas nereiškia automatinio darbo sutarties pasibaigimo. Atšaukti valdybos nariai vis dar gali išlaikyti teisę gauti atlyginimą ${ }^{47}$. Tačiau, kitaip nei Lietuvoje, valdybos nariai gali būti atšaukti anksčiau sutarto termino tik nurodant priežastị, o stebėtojų tarybos nariai - ir be priežasties ${ }^{48}$. Pagal Vokietijos teisę, valdybos nariai nèra darbuotojai griežtaja prasme ir apsauginès darbo teisès normos jiems netaikomos ${ }^{49}$. Tačiau su jais sudaromos paslaugų sutartys turi tipinių darbo sutarčių elementų dèl trukmės, kompensacijų, atostogų ir pan. Kadangi valdybos narių atšaukimas savaime nereiškia paslaugų sutarties pasibaigimo, paslaugų sutartis pasibaigia tik kai stebėtojų taryba priima atitinkamos galios teisès aktą ${ }^{50}$. Uždaro tipo bendrovès $(\mathrm{GmbH})$ direktoriaus paskyrimas taip pat yra bendrovès aktas, atskiras nuo paslaugu sutarties su direktoriumi sudarymo sandorio, todẻl direktoriaus atšaukimas savaime nenutraukia paslaugų sutarties (Uždarojo tipo akcinių bendrovių įstatymo 38 straipsnio 1 dalis) ir pareiga mokèti atlyginimą nepasibaigia ${ }^{51}$. Priešingai nei AG valdybos nariai, Uždaro tipo bendrovès $(\mathrm{GmbH})$ direktorius gali būti bet kada atšauktas be priežasties. Vokietijos teisès požiūriu tarp vadovo ir bendrovès neatsiranda darbo teisiniai santykiai, kadangi vadovas pats atlieka ir darbdavio funkcijas ${ }^{52}$. Kaip nurodo G. Jakuntavičiūtè, paslaugų sutartimi negali būti reguliuojami jokie juridinio asmens ir valdymo organo nario ,vidiniai“" santykiai, kitaip tariant, jokie juridinio asmens organų santykiai, kadangi tokie teisiniai santykiai yra išimtinis įstatymo ir juridinio asmens steigimo dokumentų reguliavimo dalykas ${ }^{53}$.

52 Kindler, P. Grundkurs Handels - und Gesellschaftsrecht. München: C. H. Beck, 2007, p. 379, cituota iš Jakuntavičiūtè, G. Juridinio asmens valdymo organu narių civiliné atsakomybè. Daktaro disertacija. Socialiniai mokslai (teisė). Vilnius: Mykolo Romerio universitetas, 2013, p. 95. 
Taigi, vadovo teisinio statuso reglamentavimas visais atvejais yra įmonių teisès sritis, o kokiu laipsniu taikomos darbo teisės normos, praktika išsiskiria. Atkreiptinas dėmesys, kad valstybių praktika išsiskiria tokiais fundamentaliais klausimais, ar darbo teisè taikoma vadovui (Nyderlanduose taikoma, Vokietijoje - ne), ar gali būti ribojama vadovo atsakomybè (Jungtinejje Karalystèje toks ribojimas draudžiamas, tuo tarpu Nyderlandų teisė leidžia akcininkų susirinkimo nutarimu atleisti vadovą nuo atsakomybės). Vis dèlto visais atvejais valstybių teisè atspindi vadovo statuso dualizmą - aplinkybę, kad jis yra ir bendrovès organas, ir ,samdos“ (paslaugų, darbo ir kt.) sutarties subjektas. Tai įrodo, kad vienodai sėkmingai gali funkcionuoti ịvairūs modeliai, svarbu, kad jie atitiktų verslo praktiką, būtų aiškūs ir normos taikymo pasekmès būtų nuspėjamos.

Lietuvos praktika rodo, kad vadovų teisiniam statusui būtinas teisinis tikrumas. Vadovų patiriama atsakomybės rizika bei socialinių ir darbo garantijų ribos turètų būti iš anksto aiškios ir bendrovei, ir vadovui, kad šie hipotetiniai kaštai galètų būti įskaičiuoti ì vadovo teikiamų paslaugų kainą. Todėl dabar galiojanti civilinė teisė kaip alternatyvus vadovo teisinio statuso reguliavimo instrumentas taip pat vertintina kritiškai. Jei vadovo teisini statusą kvalifikuotume kaip išimtinai civilinį, susidurtume su fundamentaliais neaiškumais, kurie nedidintų teisinio tikrumo. Visų pirma civilinio santykio tarp vadovo ir bendrovès kvalifikavimas - kokia civilinè sutartis sieja vadovą ir bendrovę? Teismų praktika suformavo doktriną, kad tai pavedimo sutartis, tačiau toks kvalifikavimas sunkiai suderinamas su teismų praktika dèl vadovo pareigų bendrovei ir su kai kuriomis ABI normomis. Pagrindinė problema yra susijusi su klausimu, kieno pavedimą vykdo bendrovès vadovas? Teisinis reguliavimas numato, kad bendrovès, bet bendrovè - tik teisinè fikcija, ją sudaro atskiros interesų grupès - akcininkai, kreditoriai, darbuotojai. Net jei vadovautumès samprata, kad bendrovès interesai sutampa išimtinai tik su akcininkų interesais, negalètume teigti, kad visų akcininkų - ir smulkiųų, ir dominuojančių, interesai homogeniški ir kad įmonès interesai sutampa su dominuojančio akcininko ar jų grupès interesais, o direktoriai tinkamai vykdo pareigas bendrovei atstovaudami stambiausio akcininko interesus. Dar daugiau, jei pripažinsime, kad valdymo organų tinkamas pareigų atlikimas turi atitikti skirtingų juridinio asmens interesų grupių interesus - akcininkų ir kreditorių - atsakymas, kieno pavedimą vykdo bendrovės vadovas, bus dar sudètingesnis. Lietuvos teismų praktika reflektuoja šią problemą ir pripažista, kad valdymo organų pareigos kyla bendrovei, kaip subjektui, turinčiam atskirus interesus nuo dominuojančio akcininko ${ }^{54}$, o tam tikrais atvejais ir tretiesiems asmenims - kreditoriams ${ }^{55}$. Panašios

54 Žr. Lietuvos Aukščiausiojo Teismo Civilinių bylų skyriaus teisėjų kolegijos $2000 \mathrm{~m}$. kovo 29 d. nutartị civilinėje byloje Vilniaus miesto valdyba v. UAB ,, Sangreta “ ir S. J. (bylos Nr. 3k-3-383/2000), kurioje teigiama: ,Bendrovę ir jos valdymo organus sieja fiduciariniai, t. y. tarpusavio pasitikejjimu grindžiami santykiai, todèl visi bendrovès valdymo organai privalo veikti išimtinai bendrovès interesais. Bendrovès valdymo organas privalo balsuoti prieš bet kokį nutarimą, pažeidžianti bendrovès interesus. Tais atvejais, kai bendrovès valdymo organo narys kartu yra ir bendrovės akcininkas, jo, kaip akcininko, ir jo, kaip bendrovės valdymo organo nario, interesai gali nesutapti. Taip pat gali nesutapti ir bendrovés bei jos akcininku interesai. Esant interesų konfliktui, sąžiningumo, teisingumo ir protingumo principai reikalauja, kad bendrovès valdymo organo narys apie tai informuotų kitus bendrovės valdymo organus. Tačiau vienokių ar kitokių asmeninių interesų turejjimas neatleidžia bendrovès valdymo organo nario nuo jo fiduciarinès pareigos veikti išimtinai bendrovès interesais."

55 Kasacinio teismo praktikoje laikomasi pozicijos, kad ịmonės vadovo civilinė atsakomybė gali atsirasti tiek 
pozicijos numanomai laikosi ir įstatymų leidejjas - įstatyminių pareigų ir kompetencijų valdymo organams $\mathrm{CK}$ ir ABI įtvirtinimas vertintinas kaip ịstatyminio atstovavimo elementas, nesuderinamas su pavedimo sutarties turiniu. Kad akcininkai neturi absoliučios teisès savo nuožiūra nustatyti vadovo pareigų ir riboti jo atsakomybès, iliustruoja ir ABI nuostata, pagal kurią akcininkai negali ratifikuoti valdymo organų sprendimų (pavyzdžiui, ABI 34 straipsnio 5 dalyje numatyta, kad ,(i)statuose gali būti numatyta, kad valdyba, prieš priimdama $<\ldots>$ sprendimus, turi gauti visuotinio akcininkų susirinkimo pritarimą. Visuotinio akcininkų susirinkimo pritarimas nepanaikina valdybos atsakomybės už priimtus sprendimus“"). İmonių teisès specialistai taip pat kritikuoja vadovo teisinio statuso kvalifikavimą kaip pavedimo sutarties - pozicijos, kad valdymo organų ir juridinio asmens santykio negalima kvalifikuoti kaip įstatyminio atstovavimo ir kartu pavedimo teisinio santykio laikosi ir R. Greičius ${ }^{56}$. Todèl daugiau argumentų būtų kvalifikuoti vadovą ir bendrovę siejančią sutartị kaip paslaugų, kadangi vadovas ne tiesiog vykdo akcininkų pavedimą, bet teikia paslaugas bendrovei vykdydamas įstatymines pareigas ir tik subsidiariai, kiek tai neprieštarauja imperatyviam reguliavimui, akcininkų nurodymus. Tačiau toks kvalifikavimas prieštarauja nusistovèjusiai teismų praktikai, kuri kildino akcininkų teisę bet kada atšaukti vadovus iš pavedimo sutarties esmès, todẻl mažai tikètina, kad be įstatymų reformos jis bus pakeistas.

Kitas aktualus praktikai klausimas yra teisè riboti vadovo atsakomybę bendrovei. Jei šiam klausimui būtų taikomos CK normos, t. y. bendra taisyklè dèl atsakomybès ribojimo, numatyta CK 6.252 straipsnio 1 dalyje, akcininkai bendrovès vardu galètų susitarti riboti vadovo atsakomybę su išlyga, kad žala padaryta netyčiniais veiksmais. Tačiau tokia sutarties sąlyga keltų rimtų problemų dẻl jos suderinamumo su ABI, nes jeigu akcininkai nèra vienintelè interesų grupé, kurios interesais veikia vadovai, ir akcininkai neturi kompetencijos atleisti vadovus nuo atsakomybės, juo labiau abejotina jų teisė riboti vadovų atsakomybę bendrovei. Taigi, atsakomybės ribojimo klausimais CK normos taip pat nėra pakankamas instrumentas siekiant teisinio tikrumo ir efektyvaus, verslui pritaikyto reguliavimo.

Vakarų valstybių pavyzdžiai rodo, kad Lietuva neturètų apsiriboti galiojančiomis civilinės teisès normomis kaip alternatyva dabar galiojančiai darbo teisei, kadangi šių normų taikymas lemtų dar didesnį teisinį netikrumą. Lietuvai siūlytina kurti specifinị bendrovių teisès teisinị reguliavimą, atitinkantị verslo poreikius ir suderintą su jau dabar taikoma įmonių teisės doktrina. Pagrindinė problema, kuri turètų būti išspręsta, tai sureguliuotas santykis tarp dviejų savarankiškų teisinių santykių: bendrovès sprendimų, kurių negali riboti darbo teisès normos, tačiau kurie gali keisti vadovo teisinę padètị (paskirti, atšaukti, reikalauti žalos atlyginimo iš vadovo ir pan.), ir vadovo sutarties su

įmonei, kai ịmonės vadovas veikia priešingai ịmonės interesams, tiek tretiesiems asmenims, kai įmonės vadovas pažeidžia apribojimus, nustatančius tam tikras tokių asmenų garantijas (Lietuvos Aukščiausiojo Teismo Civilinių bylų skyriaus išplèstinès teisejų kolegijos $2006 \mathrm{~m}$. gegužès $25 \mathrm{~d}$. nutartis civilinėje byloje $K$. $J$. J. v. V. K. ir kt. (bylos Nr. 3K-7-266/2006), Lietuvos Aukščiausiojo Teismo Civilinių bylų skyriaus teisèjų kolegijos $2011 \mathrm{~m}$. gegužès 5 d. nutartis civilineje byloje $U A B$,,Vajalio medienos gaminiai “ v. R. K. (bylos Nr. 3K-3-228/2011).

56 Greičius, R. Privataus juridinio asmens vadovo fiduciarinès pareigos. Vilnius: Teisinès informacijos centras, 2007, p. 125. 
bendrove, kurios sąlygos neturètų būti keičiamos dèl vẻlesnių bendrovès sprendimų. Šią santykių dichotomiją savaip išsprendè Vokietijos teisè, kuri su bendrovès priimamais sprendimais susiejo tik vadovo, kaip valdymo organo, statuso atsiradimą ir pasibaigimą, bet ne apskritai teisinio santykio su bendrove pasibaigimą, nes vadovo paslaugų sutartis nesibaigia dèl bendrovès priimtų sprendimų.

Vis dèlto Lietuva neturètų nekritiškai skolintis teisinio reguliavimo iš kitų valstybių bendrovių teisès, nesuderinusi jo su jau esamu reguliavimu, teismų praktika, esama administracine infrastruktūra ir teisine kultūra, nes kiekvieno reguliavimo modelio sèkmè priklauso nuo to, ar jis pritaikytas konkrečiam rinkos išsivystymui, teisinių ir valdžios institucijų infrastruktūroms, kultūrinèms normoms, teisinei sąmonei, kurie skirtingose valstybèse labai nevienodi ${ }^{57}$.

\section{Išvados}

1. Šiandieninis reguliavimas vadovo teisinio statuso aspektu nepateisina teisinio tikrumo lūkesčių, neatitinka verslo poreikių, neaiškus darbo teisès ir bendrovių teisès santykis. Teismų praktika, taikydama tokią teisę, veikia exnunc režimu, todèl ị daugelị civilinei apyvartai svarbių klausimų, susijusių su vadovo teisiniu statusu, negali būti pateiktas aiškus atsakymas nesikreipiant ị teismą.

2. Pagrindine doktrininė problema, kurios nepavyko išspręsti galiojančiam teisiniam reguliavimui, - tai suderinti imperatyvų darbo teisės režimą su imperatyviu bendrovių teisès reguliavimu. Juk darbo teisès normos negali ịpareigoti akcininkų susirinkimo laikytis darbo sutartyje tarp bendrovès vadovo ir bendrovès numatytų sąlygų, nekeisti jų naujais nutarimais ir pan., nes bendrovės vadovas visų pirma yra bendrovės organas, kurio veiklą reglamentuoja $\mathrm{CK}, \mathrm{ABI}$, ịstatai ir akcininkų susirinkimo nutarimai ir tik integralia darbo sutartis. Todèl nèra proporcinga ịtvirtinti darbo teisès viršenybę visų šių teisès aktų atžvilgiu.

3. Užsienio valstybėse veikia skirtingi vadovo teisinio statuso reguliavimo modeliai, bet visi jie atspindi vadovo statuso dualizmą - aplinkybę, kad jis yra ir bendrovés organas, ir kartu „samdos“ (paslaugų, darbo ir kt.) sutarties subjektas. Kadangi Lietuvos teisiniame reguliavime neatsižvelgiama ị dualistinị vadovo statusą, tą bando daryti teismų praktika.

4. Delegeferenda: atsižvelgiant ị Lietuvos teisès raidą vadovo teisinio statuso aspektu, svarstytinos dvi alternatyvos. Pirmoji alternatyva, pagal kurią vadovas išlieka darbo teisès subjektu su ypatumais, bet darbo teisès normos suderinamos su bendrovių teise vadovo teisinio statuso atžvilgiu, tokiu būdu, kad formos prasme taikomos darbo teisės normos, tačiau turinio prasme viršenybė lieka bendrovių teisei. Antroji alternatyva, pagal kurią darbo teisè ir bendrovių teisė koegzistuoja ir kiekviena iš jų reguliuoja

57 Black, B.; Kraakman, R. A self-enforcingmodelofcorporatelaw. Harvard Law Review. 1996, 109 (8): 1911-1982. Plg. Hay, J. R., et al., supra note 32. Pavyzdžiui, Vokietijos įmonių teisè yra prisitaikiusi prie stiprių bankų bei profsajungų, o JAV - prie stiprių kapitalo rinkų, silpnų finansinių institucijų ir stiprių imonių vadovų, todèl ir teisinis reguliavimas turi atspindèti tokius skirtumus. 
savarankišką santykį: bendrovių teisè - vadovo, kaip valdymo organo, santykị su bendrove, darbo teisè - vadovo, kaip vadovavimo paslaugų teikèjo, ir bendrovès santykị, o šie santykiai atsiranda ir pasibaigia savarankiškais pagrindais, taikomi savarankiški teisių gynimo būdai. Pasirinkus pirmają alternatyvą, dalis klausimų galètų būti sureguliuota ir DK.

\section{Literatūra}

Black, B.; Kraakman, R. A self-enforcing model of corporate law. Harvard Law Review. 1996: 109 (8): 1911-1982.

Corporate Business Formsin Europe. A Compendiumof Publicand Private Limited Companiesin Europe. Editedby Dornseifer, F. Sellierpublishers, 2005.

Davulis, T. Imonès, ịstaigos, organizacijos vadovo teisinio statuso problema Lietuvos teisejje. Privatine teisé: praeitis, dabartis ir ateitis: liber amicorum Valentinas Mikelenas. Vilnius: Justitia, 2008, p. 99-115.

Greičius, R. Privataus juridinio asmens vadovo fiduciarinès pareigos. Vilnius: Teisinès informacijos centras, 2007.

Hay, J. R.;Shleifer, A.; Vishny, R. W. Toward a theoryoflegalreform. European Economic Review. 1996, 49: 559-567.

Jakuntavičiūtè, G. Juridinio asmens valdymo organu nariu civiliné atsakomybè. Daktaro disertacija. Socialiniai mokslai (teisè). Vilnius: Mykolo Romerio universitetas, 2013.

Jungtinès Karalystės 2006 m. Bendrovių įstatymas (Companies Act 2006) [interaktyvus]. [žiūrèta 2013-07-01]. <http://www.legislation.gov.uk/ ukpga/2006/46/contents $>$.

Lietuvos Aukščiausiojo Teismo Civilinių bylų skyriaus teisëjų kolegijos $2001 \mathrm{~m}$. lapkričio 26 d. nutartis civilinèje byloje $P$. D. v. $A B$ „Žalvaris “ (byla Nr. 3K-3-1200).

Lietuvos Aukščiausiojo Teismo Civilinių bylų skyriaus teisèjų kolegijos $2011 \mathrm{~m}$. gegužès 5 d. nutartis civilineje byloje $U A B$, ,Vajalio medienos gaminiai" v. R. K. (bylos Nr. 3K-3228/2011).

Lietuvos Aukščiausiojo Teismo Civilinių bylų skyriaus išplèstinès teisèjų kolegijos $2006 \mathrm{~m}$. gegužès $25 \mathrm{~d}$. nutartis civilineje byloje $K . J$. J. v. V. K. ir kt. (bylos Nr. 3K-7-266/2006).

Lietuvos Aukščiausiojo Teismo Civilinių bylų skyriaus teisejų kolegijos $2001 \mathrm{~m}$. spalio $16 \mathrm{~d}$. nutartis civilineje byloje $V . P$. v. Radviliškio rajono savivaldybe, $U A B$, ,Radviliškio autobusu parkas" (bylos Nr. 3K-7-760/2001).

Lietuvos Aukščiausiojo Teismo Civilinių bylų skyriaus teisèjų kolegijos 2009 m. lapkričio 20 d. nutartis civilinèje byloje $B U A B,, O p$ timalūs finansai" v. G. P. (bylos Nr. 3K-7444/2009).

Lietuvos Aukščiausiojo Teismo Civilinių bylų skyriaus teisèjų kolegijos 2012 m. lapkričio 16 d. nutartis civilinèje byloje Bankrutuojanti $U A B$,IBCA trobos “ v. A. G. (bylos Nr. 3K3-493/2012).

Lietuvos Aukščiausiojo Teismo Civilinių bylų skyriaus teisèjų kolegijos $2003 \mathrm{~m}$. sausio $8 \mathrm{~d}$. nutartis civilinèje byloje Z. Z. v. UAB , Šiauliu aerouostas " (byla Nr. 3K-3-6/2003).

Lietuvos Aukščiausiojo Teismo Civilinių bylų skyriaus teisèjų kolegijos $2006 \mathrm{~m}$. vasario $15 \mathrm{~d}$. nutartis civilinejje byloje $V$. S. v. Kooperatine bendrove Lietuvos kooperatyvu sajunga (byla Nr. 3K-3-123/2006).

Lietuvos Aukščiausiojo Teismo Civilinių bylų skyriaus teisèju kolegijos $2007 \mathrm{~m}$. spalio $12 \mathrm{~d}$. nutartis civilinèje byloje $A$. M. v. UAB ,Vités valdos" (bylos Nr. 3K-3-397/2007).

Lietuvos Aukščiausiojo Teismo Civilinių bylų skyriaus teisejų kolegijos $2010 \mathrm{~m}$. balandžio 30 d. nutartis civilineje byloje J. B. B. v. UAB „Neogroup“ (bylos Nr. 3K-3-157/2010).

Lietuvos Aukščiausiojo Teismo Civilinių bylų skyriaus teisèjų kolegijos $2012 \mathrm{~m}$. gegužès 28 d. nutartis civilineje byloje J. B. v. AB Turto bankas (bylos Nr. 3K-3-252/2012).

Lietuvos Aukščiausiojo Teismo Civilinių bylų skyriaus teisèjų kolegijos $2011 \mathrm{~m}$. gruodžio 19 d. nutarti civilinèje byloje Lietuvos Respublikos švietimo ir mokslo ministerija $v$. UAB ,Mokslo aidai" direktorius J. S., likviduojama $U A B$,Mokslo aidai“ ir kt. (bylos Nr. 3K-3-535/2011). 
Lietuvos Aukščiausiojo Teismo Civilinių bylų skyriaus teisèjų kolegijos 2009 m. gruodžio 18 d. nutartyje civilineje byloje $A B$,,Mažeikiu nafta " v. I. D. (I. D.) ir kt. (bylos Nr. 3K-3446/2009).

Lietuvos Aukščiausiojo Teismo Civilinių bylų skyriaus teisejų kolegijos $2009 \mathrm{~m}$. liepos $9 \mathrm{~d}$. nutartis civilinèje byloje $B U A B$,Alveronas “ v. I. S., R. P. ir kt. (bylos Nr. 3K-3-329/2009). Lietuvos Aukščiausiojo Teismo Civilinių bylų skyriaus teisèjų kolegijos $2007 \mathrm{~m}$. kovo $26 \mathrm{~d}$. nutartis civilineje byloje Antstolis A. S. v. UAB „Biriu kroviniu terminalas “ (bylos Nr. 3K-3238/2007).

Lietuvos Aukščiausiojo Teismo Civilinių bylų skyriaus teisèjų kolegijos $2000 \mathrm{~m}$. kovo $29 \mathrm{~d}$. nutarti civilinèje byloje Vilniaus miesto valdyba v. UAB , Sangreta “ ir S. J. (bylos Nr. 3k-3$383 / 2000)$.
Lietuvos Respublikos akcinių bendrovių įstatymas. Valstybès žinios. 2000, Nr. 64-1914.

Mikelènas, V., et al. Lietuvos Respublikos civilinio kodekso komentaras. Antroji knyga. Vilnius: Justitia, 2002.

Lietuvos Respublikos civilinis kodeksas. Valstybès žinios. 2000, Nr. 74-2262.

Lietuvos Respublikos darbo kodeksas. Valstybès žinios. 2002, Nr. 64-2569.

Martišienè, B. Darbo santykiu reguliavimo civiliniai teisiniai aspektai. Daktaro disertacija. Socialiniai mokslai (teisè). Vilnius: Vilniaus universitetas, 2012.

Vokietijos Akciniu bendrovių įstatymas (AktG) [interaktyvus]. [žiūrèta 2013-07-01]. <http:// www.gesetze-im-internet.de/aktg/>.

Vokietijos Uždaro tipo bendrovių îstatymas (GmbHG) [interaktyvus]. [žiūrèta 2013-07-01]. $<$ http://www.gesetze-im-internet.de/gmbhg/>.

\title{
LEGAL STATUS OF THE SOLE MANAGING BODY: IS UNAMBIGUOUSNESS POSSIBLE?
}

\author{
Agnè Tikniūtè, Jūratė Usonienè
}

Mykolas Romeris University, Lithuania

Summary. The article analyses the key issues of the legal status of the sole managing body from the perspective of the valid legal regulation, the established case-law and doctrine.

The first part of the article analyses the dualism of the manager's legal status from the perspective of civil law and labour law. The analysis of the latest case-law presented herein shows that the rule of "internal" and "external" relations between the manager and the company formulated in the case-law is applied differently, and the criterion of distinguishing the manager's as the subject of the labour law and that of the civil law statuses still remains unclear. The authors of the article are of the view that due to insufficient legal regulation in force rules established by the case-law to regulate the manager's legal status cannot ensure the required legal certainty. Thus, the reform of the manager's legal regulation is essential.

The second part of the article strives to answer the question what legal regulation models exist and what are the main criteria of quality legal regulation. The comparative analysis of the legal status regulation of the sole managing body allows to determine the main available regulation models of the manager's legal status and to distinguish their advantages and disadvantages. The authors of the article believe that it is necessary to take regard to other states' practices regulating the relations at issue, however, while creating such legal regulation, the evaluation of economic, cultural and social peculiarities of Lithuania is also required. In search for the most appropriate model of the manager's legal status, attention should be drawn to the fact that in some aspects the labour law regime is too restrictive (e.g., shareholders 
cannot recall the manager, who is on maternal leave, and the manager at interim does not have full authority) and uncoordinated with the doctrine of the companies' law. Moreover, quite a few questions directly related to the issues of the manager's authority do not fall or only partially fall into the scope of the labour law. On the other hand, the problem of the manager's legal status involves a broader scope of points of the companies' law than the dualism of the manager's status, and a part of these points has already been regulated by the Law on Companies (the agreement conclusion, termination, removal from the register of legal persons, terms of notice). In regard to this, a question can be raised if it not be better to regulate the issues of the manager's legal status by the provisions of the Law on Companies and not of the Labour Code. It is proposed to create a specific legal regulation of the companies' law, which could meet the needs of business and match up to the doctrine of the companies' law, which is already being applied.

Keywords: Sole Managing Body, manager's legal status, legal relations between the manager and the company, legal responsibility of the manager.

Agnė Tikniūtė, Mykolo Romerio universiteto Teisès fakulteto Civilinès justicijos instituto docentė. Mokslinių tyrimų kryptys: bendrovių teisė, atstovavimo institutas, valdymo organų atsakomybe்.

Agnè Tikniūtė, Mykolas Romeris University, Faculty of Law, Institute of Civil Justice, Assoc. Professor. Research interests: companies' law, representation, responsibility of management bodies.

Jūratė Usonienė, Mykolo Romerio universiteto Teisės fakulteto Civilinės justicijos instituto profesorè. Mokslinių tyrimų kryptys: sutarčių teisè, civilinè atsakomybė, intelektinès nuosavybès teisè.

Jūratė Usonienė, Mykolas Romeris University, Faculty of Law, Institute of Civil Justice, Professor. Research interests: contract law, torts, intellectual property law. 